\title{
RANCANG BANGUN DAPUR CRUCIBLE TIPE PENUANGAN TUNGKIK KAPASITAS 15 KG DENGAN BAHAN BAKAR GAS LPG
}

\author{
Ipung Kurniawan ${ }^{1}$, Bayu Aji Girawan ${ }^{2}$, Saeful Nurrohman ${ }^{3}$ \\ 1,2,3 Program Studi Teknik Mesin - Politeknik Negeri Cilacap
}

\begin{abstract}
Abstrak
Kata Kunci:

Dapur Crucible,

Aluminium,

Komposisi Kimia.

Penelitian ini bertujuan; 1) Merancang dan membuat dapur crucible peleburan aluminium kapasitas $15 \mathrm{~kg}$; 2) Melakukan pengujian komposisi kimia hasil peleburan pertama dan kedua. Studi lapangan dan kajian pustaka digunakan dalam metode penelitian ini. Hasil dari rancangan didapatkan dimensi dapur peleburan; diameter $457 \mathrm{~mm}$, tebal $3 \mathrm{~mm}$, tinggi $410 \mathrm{~mm}$. Sedangkan untuk cawan lebur berdimensi; dameter $178 \mathrm{~mm}$, tebal $8 \mathrm{~mm}$, tinggi $230 \mathrm{~mm}$. Hasil pengujian komposisi kimia peleburan pertama dan kedua tidak ada perubahan yang signifikan. Material hasil peleburan pertama masih mengandung aluminium (Al) 89,52\% sedangkan paduan utamanya adalah seng ( $\mathrm{Zn}$ ) 7,71\% dan Silikon (Si) 1,84\% dan pada peleburan kedua masih mengandung aluminium (Al) 89,55\% sedangkan paduan utamanya adalah seng ( $\mathrm{Zn}$ ) 7,51\% dan Silikon (Si) 1,94\%.
\end{abstract}

\footnotetext{
Abstract

Keywords:

Crucible Casting,

Aluminium, Chemical

Composition

\begin{abstract}
This research aims to; 1) Designing and making aluminium melting crucible casting with the capacity $15 \mathrm{~kg}$; 2) Conducting the test of chemical composition of the first and second melting result. The research used field and library research. From the result of the design, it could be obtained that the dimension of melting casting has $547 \mathrm{~mm}$ diameter, $3 \mathrm{~mm}$ thick, $410 \mathrm{~mm}$ high. Whereas, molten cup has $178 \mathrm{~mm}$ diameter, $8 \mathrm{~mm}$ thick, and $230 \mathrm{~mm}$ high. The result of the first melting chemical composition test and the second one do not work out a significant change. The material of the first melting result still contains $89,52 \%$ of aluminium ( $\mathrm{Al})$, while the main fusion is $7,71 \%$ of zinc $(\mathrm{Zn})$ and $1,84 \%$ of silicon (Si), and in the second melting result still contains $89,55 \%$ of Alumunium (Al), while the main fusion is $7,51 \%$ of zinc ( $\mathrm{Zn}$ ) and 1,94\% of silicon (Si).
\end{abstract}




\section{PENDAHULUAN}

\section{Latar Belakang}

Perkembangan industri peleburan dan pengecoran logam di Indonesia khususnya provinsi Jawa Tengah saat ini sangat rendah. Padahal Indonesia berpotensi menjadi salah satu pasar terbesar di dunia. Industri pengecoran logam berskala kecil banyak yang terkendala perkembangannya, hal ini disebabkan oleh dapur peleburan logam yang tersedia di pasaran sangat mahal harganya dan susah untuk didapatkan kerena harus diimpor dari luar negeri. Pemilihan tungku peleburan yang akan digunakan untuk mencairkan logam harus sesuai dengan bahan baku yang akan dilebur. Paduan alumunium, paduan tembaga, paduan timah hitam, dan paduan ringan lainnya biasanya dilebur dengan menggunakan tungku peleburan jenis crusible, sedangkan untuk besi cor menggunakan tungku induksi frekwensi rendah atau kupola. Tungku induksi frekwensi tinggi biasanya digunakan untuk melebur baja dan material tahan temperatur tinggi ${ }^{[1]}$.

Jenis dan klasifikasi dapur peleburan yang saat ini berkembang diantaranya adalah dapur krusibel, dapur kupola, dapur busur listrik, dapur induksi, dapur konverter, dan dapur Thomas dan Bessemer. Bahan bakar yang digunakan juga beragam diantaranya batu bara, bahan bakar minyak, listrik, arang, bahkan bahan bakar berbentuk gas ${ }^{[2]}$. Faktor-faktor pemilihan tungku antara lain seperti jenis logam yang akan dicor, desain temperatur lebur dan temperatur penuangan, kemampuan atau kapasitas tungku yang mampu dilebur, biaya operasi yang dibutuhkan, kemudahan pengoperasian, kemudahan perawatan, dan polusi terhadap lingkungan ${ }^{[3]}$.

Untuk menjawab permasalahan diatas diperlukan suatu perancangan dan pembuatan dapur peleburan yang sederhana, mudah dibuat, mudah dipindah-pindahkan (portable) dan yang tidak kalah pentingnya yaitu harga terjangkau oleh industriindustri berskala rumah tangga. Dapur peleburan logam hasil perancangan dan pembuatan tersebut akan memiliki beberapa keunggulan diantaranya adalah efisiensi bahan bakarnya karena menggunakan bahan bakar gas (LPG) dan temperatur ruang bakar yang mencapai $1000{ }^{\circ} \mathrm{C}$ karena kontruksi dapur menggunakan isolasi panas bata tahan api. Untuk itu, perlu mendapatkan sebuah rancangan dapur peleburan alumunium yang relatif murah dengan mengunakan bahan bakar gas (LPG).

\section{Tujuan}

Tujuan dari penelitian ini diantaranya adalah;

1) Merancang dan membuat dapur crucible untuk peleburan aluminium berkapasitas $15 \mathrm{~kg}$,

2) Melakukan pengujian komposisi kimia hasil peleburan pertama dan kedua.

\section{Tinjauan Pustaka}

Mubarak dan Akhyar ${ }^{[4]}$, telah merancang dan membuat tungku peleburan logam dengan menggunakan bahan bakar gas LPG, dalam penelitian tersebut di lakukan pengujian lebur aluminum bekas. Hasil yang diperoleh adalah logam aluminium dapat melebur, akan tetapi logam aluminium bekas tersebut saat dileburkan tidak mencair secara sempurna. Masih terdapat fasa pada diantara fasa cair serta untuk mencairkan aluminium dengan melting point sekitar $660{ }^{\circ} \mathrm{C}$ membutuhkan waktu antara 2 sampai 3 jam.

Arianto L.S, dkk. ${ }^{[5]}$ telah merancang dan membuat tungku peleburan aluminium dengan menmbahkan economizer sebagai inovasi. Pada perancangannya saluran buang pada tungku berdiameter sama dengan saluran masuk. Saluran dibuat memanjang dan berbelok berfungsi sebagai economizer yang mampu meningkatkan suhu dalam tungku dan meningkatkan efisiensi proses peleburan. Aluminium $11,78 \mathrm{~kg}$ dicairkan oleh tungku dengan economizer dalam 60 menit dan membutuhkan 2,6 kg gas LPG, sedang tungku tanpa economizer membutuhkan 3,1 kg gas LPG dan waktu 80 menit.

Aluminium merupakan material yang luas penggunaannya. Hal ini disebabkan karena Aluminium mempunyai sifat yang istimewa dibandingkan dengan logam lainnya. Diantara kelebihan Aluminium adalah: ringan, ulet, kuat, ketahanan korosi tinggi serta mempunyai konduktivitas panas dan daya hantar panas yang baik. Tabel 1 Sifat fisik $\mathrm{Al}^{[6]}$

\begin{tabular}{ccccc} 
Element & Symbol & $\begin{array}{c}\text { Atomic } \\
\text { weight }\end{array}$ & $\begin{array}{c}\text { Melting } \\
\text { point }\left({ }^{\circ} \mathrm{C}\right)\end{array}$ & $\begin{array}{c}\text { Boiling } \\
\text { Point }\left({ }^{\circ} \mathrm{C}\right)\end{array}$ \\
Aluminium & $\mathrm{Al}$ & 26.97 & 660.4 & 2520 \\
\hline
\end{tabular}

\begin{tabular}{|c|c|c|c|c|}
\hline \multicolumn{2}{|c|}{$\begin{array}{l}\text { Latent heat of } \\
\text { fusion }\end{array}$} & \multicolumn{2}{|c|}{$\begin{array}{c}\text { Mean specific heat } \\
0-100^{\circ} \mathrm{C}\end{array}$} & \multirow{2}{*}{$\begin{array}{l}\text { Thermal } \\
\text { conductivity } \\
\text { (W/m.K) }\end{array}$} \\
\hline$\overline{(\mathrm{kJ} / \mathrm{kg})}$ & $(\mathrm{cal} / \mathrm{g})$ & (kJ/kg.K) & $\left(\mathrm{cal} / \mathrm{g}^{0} \mathrm{C}\right)$ & \\
\hline 386.8 & 92.4 & 0.917 & 0.219 & 238 \\
\hline
\end{tabular}

\begin{tabular}{ccccc}
$\begin{array}{c}\text { Resistivity } \\
(\mu \mathrm{ohm} . \mathrm{cm} \\
\text { at 200C) }\end{array}$ & $\begin{array}{c}\text { Vol. } \\
\text { change } \\
\text { on } \\
\text { melting } \\
(\%)\end{array}$ & $\begin{array}{c}\text { Density } \\
(\mathrm{g} / \mathrm{cm})\end{array}$ & $\begin{array}{c}\text { Coeff. Of } \\
\text { expansion } \\
(\mathbf{x} 10-6 / K)\end{array}$ & $\begin{array}{c}\text { Brinell } \\
\text { hardness } \\
\text { no. }\end{array}$ \\
\hline 2.67 & 6.6 & 2.70 & 23.5 & 17 \\
\hline
\end{tabular}

Aluminium memiliki ketahanan terhadap korosi yang baik pada beberapa kondisi lingkungan karena permukaan aluminium mampu membentuk lapisan alumina $\left(\mathrm{Al}_{2} \mathrm{O}_{3}\right)$ bila bereaksi dengan oksigen. Struktur kristal yang dimiliki aluminium adalah struktur kristal FCC (Face Centered Cubic), sehingga aluminium tetap ulet meskipun pada temperatur yang sangat rendah. Keuletan yang tinggi dari aluminium menyebabkan logam tersebut mudah dibentuk atau mempunyai sifat mampu bentuk yang baik.

Seperti logam murni lainnya, aluminium memiliki kekuatan yang rendah dan tidak dapat langsung diaplikasikan karena ketahanan deformasi dan patahnya kurang tinggi. Oleh karena itu perlu adanya penambahan elemen lain ke dalam aluminium. Sifat aluminium tergantung dari interaksi komposisi kimia dan struktur mikro yang berkembang selama solidifikasi, perlakukan panas, dan proses deformasi (untuk produk tempa) ${ }^{[7]}$.

Gas LPG merupakan bahan bakar gas yang di cairkan (Liquified petroleum gas), merupakan produk 
minyak bumi yang diperoleh dari proses distilasi bertekanan tinggi. Fraksi yang digunakan sebagai umpan dapat berasal dari beberapa sumber yaitu gas alam maupun gas hasil dari pengolahan minyak bumi. utama LPG terdiri dari Hidrokarbon ringan berupa propana $\left(\mathrm{C}_{3} \mathrm{H}_{8}\right)$ dan Butana $\left(\mathrm{C}_{4} \mathrm{H}_{10}\right)$, serta sejumlah kecil Etana $\left(\mathrm{C}_{2} \mathrm{H}_{6}\right)$, dan Pentana $\left(\mathrm{C}_{5} \mathrm{H}_{12}\right)$, LPG digunakan sebagai bahan bakar untuk rumah tangga dan industri. LPG terutama digunakan oleh masyarakat tingkat menengah keatas yang kebutuhan semakin meningkat dari tahun ketahun kerena termasuk bahan bakar yang ramah lingkungan. Sebagai bahan bakar untuk keperluan rumah tangga, LPG harus memenuhi beberapa persyaratan khusus dengan tujuan agar aman dipakai dalam arti tidak membahayakan bagi sipemakai dan tidak merusak peralatan yang digunakan serta effisien dalam pemakaian. Oleh sebab itu untuk menjaga faktor keselamatan, LPG dimasukan ke dalam tabung yang tahan terhadap tekanan yang terbuat dari besi baja dan dilengkapi dengan suatu pengatur tekanan, disamping itu untuk mendeteksi terjadi kebocoran LPG, maka LPG sebelum dipasarkan terlebih dahulu ditambah zat pembau (odor)sehingga apabila terjadi kebocoran segera diketahui ${ }^{[8]}$.

Dapur adalah sebuah peralatan yang digunakan untuk mencairkan logam pada proses pengecoran (casting) atau untuk memanaskan bahan dalam proses perlakuan panas (heat Treatmet). Karena gas buang dari bahan bakar berkontak langsung dengan bahan baku, maka jenis bahan bakar yang dipilih menjadi penting. Sebagai contoh, beberapa bahan tidak akan mentolerir sulfur dalam bahan bakar. Bahan bakar padat akan menghasilkan bahan partikulat yang akan mengganggu bahan baku yang ditempatkan didalam dapur ${ }^{[1]}$.

Idealnya dapur harus memanaskan bahan sebanyak mungkin sampai mencapai suhu yang seragam dengan bahan bakar dan tenaga kerja sesedikit mungkin. Kunci dari operasi dapur yang efisien terletak pada pembakaran bahan bakar yang sempurna dengan udara berlebih yang minimum. Dapur beroperasi dengan efisiensi yang relatif rendah (dibawah $70 \%$ ) dibandingkan dengan peralatan pembakaran lainnya seperti boiler (dengan efisiensi lebih dari 90 \%). Hal ini disebabkan oleh suhu operasi yang tinggi didalam dapur. Sebagai contoh, sebuah dapur yang memanaskan bahan sampai suhu $1200{ }^{\circ} \mathrm{C}$ akan mengemisikan gas buang pada suhu $1200{ }^{\circ} \mathrm{C}$ atau lebih yang mengakibatkan kehilangan panas yang cukup signifikan ${ }^{[1]}$.

Dapur ini melebur logam tanpa berhubungan langsung dengan bahan pembakaran (indirect fuelfired furnance).
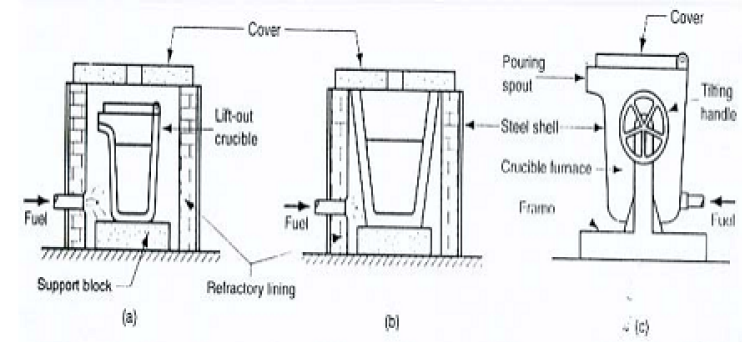

Gambar 1 Tiga jenis dapur Crusible

Dalam gambar 1 ditunjukkan tiga jenis dapur krusibel yang biasa digunakan :

a. Krusibel angkat (lift-out krusibel),

b. Pot tetap (stationary pot),

c. Dapur tukik (tilting-pot furnance).

\section{METODOLOGI PENELITIAN}

Dalam menyelesaikan penelitian ini, metode yang dilakukan adalah pengamatan lapangan terhadap dapur peleburan aluminium pada industri rumah tangga dan dilakukan kajian pustaka sebagai bahan pertimbangan untuk melihat kemungkinan dilakukan perbaikan-perbaikan. Aluminium hasil peleburan diperoleh dari limbah aluminium bekas yang didapat dari pengepul. Proses pembuatan dapur peleburan dilakukan di Laboratorium Teknik Mesin Politeknik Negeri Cilacap. Sedangkan pengujian komposisi kimia hasil peleburan aluminium dilakukan di Laboratorium Pengujian Logam Politeknik Manufaktur Ceper.

\section{HASIL DAN PEMBAHASAN Perancangan}

Perancangan merupakan suatu kegiatan awal dari suatu rangkaian kegiatan dalam proses pembuatan produk. Dalam pembuatan produk sangat diperlukan suatu gambaran yang digunakan untuk dasar-dasar dalam melangkah atau bekerja. Gambaran ini dapat disajikan dalam bentuk diagram alir sebagai metode dalam perencanaan dan perancangan. Metode perencanan dan perancangan memodifikasi dan merujuk dari metode perencanaan menurut Pahl dan Beitz yang terbagi menjadi empat tahap ${ }^{[9]}$;

1. Menetapkan kebutuhan

Tahap ini dilakukan dengan menetapkan kebutuhan produk yang akan dibuat. Langkahlangkah yang dapat dilakukan dalam menetapkan kebutuhan diantarnya adalah:

a. Melakukan analisa pasar

b. Berdasarkan permintaaan konsumen

2. Perancangan konsep produk

Tahap ini mencari alternatif fungsi dan sub fungsi dari produk, kemudian dikombinasikan menjadi konsep produk. Beberapa konsep dinilai dan dipilih menjadi satu konsep terbaik. Dalam pemilihan konsep produk digunakan metode seleksi konsep Stuart Pugh. 
3. Perancangan Detail (embodyment)

Tahap ini menetukan niliai - nilai terukur dari konsep terbaik. Nilai - nilai didapat dari perhitungan, komputasi, analisis, empirik, standar, perbandingan, konsultasi sampai justifikasi

4. Dokumen pembuatan produk (documentation) Tahap dokumentasi difokuskan untuk mendukung fabrikasi, yaitu :

a. Gambar susunan produk

b. Gambar paduan (assembly)

c. Gambr detail komponen

d. Bill of material

e. Keterangan pendukung tambahan

f. Laporan tertulis

\section{Kapasitas Cawan}

Pada perencanaan ini cawan lebur yang dipakai adalah pipa silinder yang terbuat dari baja karbon rendah dengan ukuran diameter $178 \mathrm{~mm}$, tebal $8 \mathrm{~mm}$ dan tinggi $230 \mathrm{~mm}$. Pada bagian atas pipa baja tersebut dibuat berlubang sedangkan bagian bawah dibuat alas atau tertutup. Kapasitas dari logam cair yang dapat ditampung di dalam cawan lebur dapat dicari dengan menggunakan rumus berikut ${ }^{[10]}$ :

Dimana:

$$
W_{\text {maks }}=V c \cdot \rho_{a l}
$$

$\mathrm{Vc}=$ Volume cawan

$\rho_{\mathrm{al}}=$ Massa jenis aluminium

Sehingga didapat kapasitas cawan lebur sebesar 17,73 $\mathrm{kg}$, kapasitas ini mencukupi untuk kapasitas yang drencanakan yaitu $15 \mathrm{~kg}$.

\section{Jumlah Bata Tahan Api}

Bata tahan api merupakan bahan isolator panas dari panas yang terjadi selama peleburan berlangsung. Kebutuhan jumlah bata tahan api yang diperlukan dapat dihitung menggunakan rumus berikut;

Tipe tempat lingkaran $=\frac{\text { Tinggi dapur } x \text { Jumlah batas tiap lapis }}{\text { Tebal bata tahan api }}$

Dimana:

Tinggi dapar

$: 410 \mathrm{~mm}$

Jumlah batas tiap lapis : $2 \mathrm{~mm}$

Tebal bata tahan api $: 50 \mathrm{~mm}$

Sehingga kebutuhan bata tahan api sebesar 17 buah.

\section{Hasil Perancangan}

Berdasarkan evaluasi hasil perancangan, maka diperoleh bentuk akhir dapur peleburan aluminium sebagai berikut:

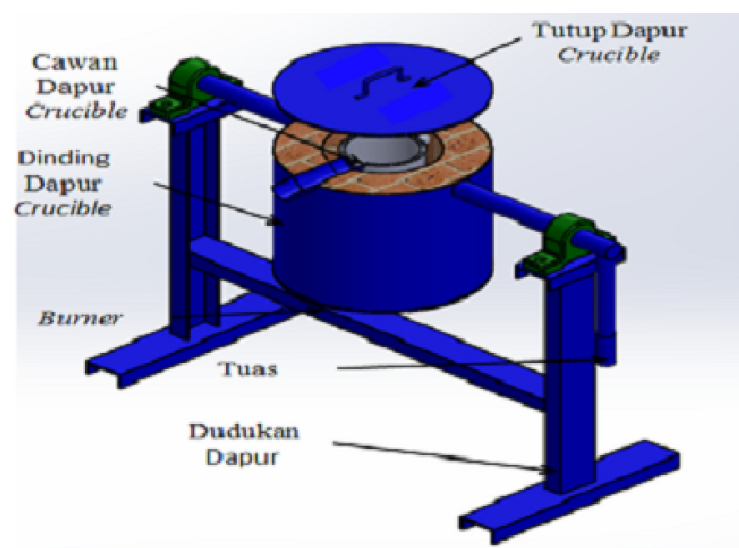

Gambar 2 desain rancanga dapur crucible

\section{Hasil Uji Komposisi Kimia}

Hasil pengujian komposisi kimia pada aluminium menggunakan Dapur Crucible adalah sebagai berikut:

Dari Hasil pengujian dengan peleburan pertama diperoleh bahwa material uji mempunyai 17 unsur penyusun komposisi kimia dimana material tersebut adalah aluminium yang mempunyai komposisi kimia sebanyak 89,52 \% berupa Al (Aluminium). Dan komposisi paduan lain yang utama adalah Seng sebanyak 7,71\%. Sedangkan unsur yang lain masih sangat kecil nilainya atau hampir mendekati angka nol. Seperti yang ditunjukkan pada tabel 2. Jika hasil tersebut digambarkan menjadi diagram maka gambarnya dapat dilihat pada gambar 3 .
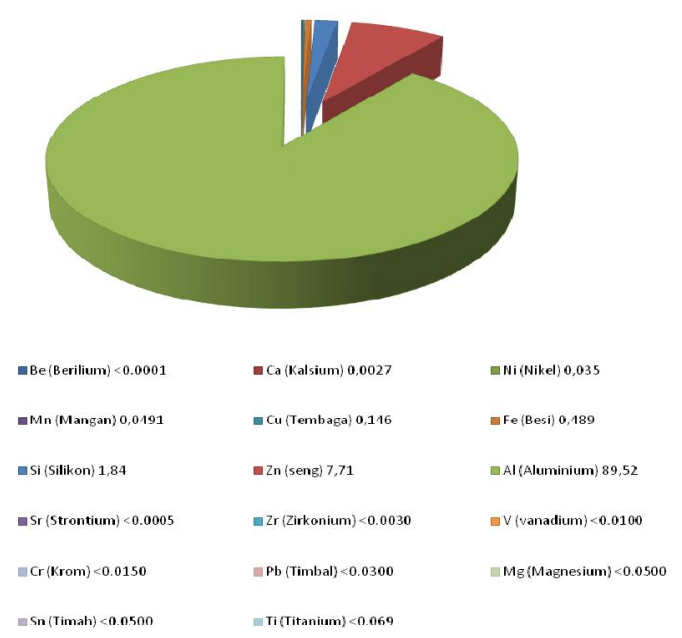

Gambar 3 hasil pengujian komposisi kimia peleburan yang pertama

Jika dibandingkan dengan hasil peleburan kedua maka hasil pengujian komposisi kima tidaklah jauh berbeda dimana dari peleburan yang ada diagram komposisi kimianya dapat dilihat pada gambar 4 . 


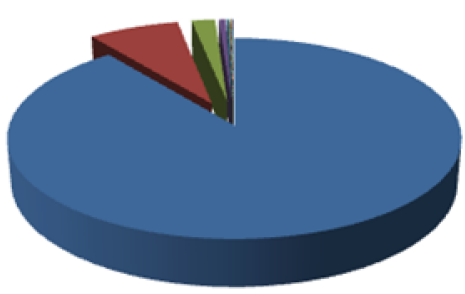

al (Aluminium) 89,55

an (Seng) 7,51

- Si (Silikon) 1,94

a Fe (Besi) 0,574

- Cu (Tembaga) 0,146

- Mn (Mangan) 0,0431

Gambar 4 hasil pengujian komposisi kimia peleburan yang kedua

Dari kedua data yang diperoleh dari hasil pengujian yang ada dibandingkan maka dibuat tabel pembanding:

Tabel 2 hasil perbandingan komposisi kimia peleburan pertama dan kedua

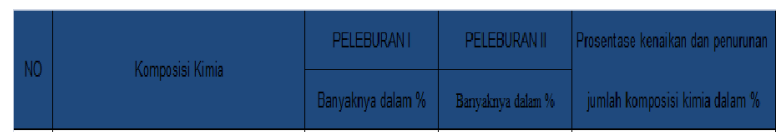

\begin{tabular}{|c|c|c|c|c|}
\hline 1 & $\mathrm{Al}$ (Aluminium) & 89,52 & 89,55 & naik sebanyak 0,03 \\
\hline 2 & Zn iseng) & 7,71 & 7,51 & turun sebanyak 0,20 \\
\hline 3 & \$i (Silkon) & 1,84 & 1,4 & naik sebanyak 0,10 \\
\hline 4 & $\mathrm{Fe}(\mathrm{Besi})$ & 0,469 & 0,574 & nalk sebanyak 0,085 \\
\hline 5 & Cu (Țembaga) & 0,146 & 0,146 & tetap \\
\hline 6 & Mn (Margan) & 0,0491 & 0,0431 & naik sebanyak 0,060 \\
\hline 1 & Ni (Nikel) & 0,035 & 0,025 & naik sebanyak 0,01 \\
\hline 8 & $\mathrm{Ca}$ (Kalsium) & 0,0027 & 0,051 & naik sebanyak 0,0483 \\
\hline 9 & $T$ T(Titanium) & $\$ 0.069$ & 0,0668 & tunun sebanyak 0,03 \\
\hline 10 & Mg (Magnesium) & $<0.0500$ & 0,05 & tetap \\
\hline 11 & Sn (Timah) & $<0.0500$ & 0,05 & tetap \\
\hline 12 & $\mathrm{~Pb}$ (Timbal) & $<0.0300$ & 0,03 & tetap \\
\hline 13 & Cr (Krom) & $<0.0150$ & 0,015 & telap \\
\hline 14 & V(vanadium) & $<0.0100$ & 0,01 & tetap \\
\hline 15 & Zr (Zirkonium) & $<0.0030$ & 0,0153 & naik sebanyalk 0,0123 \\
\hline 16 & $\operatorname{Sr}$ (Strontium) & $<0.0005$ & 0,0003 & tetap \\
\hline 17 & Be (Berilium) & 80.0001 & 0,0001 & tetap \\
\hline
\end{tabular}

Dari analisa komposisi kimia menunjukan bahwa material pertama masih mengandung banyak aluminium (Al) yaitu sebesar 89,52\% sedangkan pada peleburan kedua aluminium sebanyak 89,55\% mengalami kenaikan sebesar $0,03 \%$ disebabkan karena pada peleburan kedua menyisakan beberapa material sisa alumunium dari peleburan pertama yang terendap pada dasar cawan dan mengeras sehingga saat Dapur Crucible sampai pada suhu $660^{\circ}$ atau melting point aluminium yang terendap akan melebur bersama pada peleburan kedua.

Unsur paduan terbesar pada paduan aluminium ini adalah seng $(\mathrm{Zn})$ sebesar 7,71\% pada peleburan pertama dan seng $(\mathrm{Zn})$ sebesar $7,51 \%$ pada peleburan kedua mengalami penurunan sebesar $0,20 \%$ dikarenakan komposisi kimia seng pada peleburan kedua terlarut pada dasar cawan dan pada proses pengecoran yang dilakukan hanya mengecor bagian atas sehingga kandungan seng menurun dan berakibat pada hasil material memberi sifat memudahkan proses casting dan menaikkan kemampuan mekanis pada hasil peleburan.

Unsur paduan terbesar kedua pada paduan aluminium ini adalah silikon ( $\mathrm{Si}$ ) sebesar 1,84\% pada peleburan pertama dan silikon (Si) sebesar 1,94\% pada peleburan kedua mengalami kenaikan sebesar $0,10 \%$ pada dasarnya silikon mempunyai pengaruh keuntungan yaitu memudahkan proses flow dan casting, memudahkan proses welding, memperkecil daya lentur, mencegah perubahan suhu yang terlalu cepat dan kerugiannya adalah sulit untuk proses pemotongan dan daya rekat jelek.

Unsur paduan pada paduan aluminium ini adalah besi (Fe) sebesar $0,489 \%$ pada paduan pertama dan besi (Fe) sebesar 0,574\% mengalami kenaikan sebesar 0,085\% pada dasarnya besi keuntungan mencegah part menempel pada dies dan kerugiannya menurunkan kualitas mekanis dan menimbulkan hard spot pada hasil peleburan.

Dari hasil perbandingan peleburan kedua dan peleburan pertama juga tidak terjadi peningkatan ataupun penurunan pada unsur paduan yaitu $\mathrm{Cu}$ (Tembaga), Mn (Mangan), Ni (Nikel), Ca (Kalsium), Ti (Titanium), Mg (Magnesium), Sn (Timah), $\mathrm{Pb}$ (Timbal), Cr (Krom), V (vanadium), Zr (Zirkonium), Sr (Strontium), dan Be (Berilium).

Unsur paduan pada paduan aluminium ini adalah Mn (Mangan) sebesar 0,0491\% pada paduan pertama dan Mn (Mangan) sebesar 0,0431\% mengalami kenaikan sebesar $0,060 \%$ pada dasarnya Mangan (Mn) mempunyai keuntungan tahan temperatur tinggi memperkecil kerusakan akibat Fe dan kerugian unsur ini adalah daya serap panas berkurang dan menimbulkan hard spot.

Unsur paduan pada paduan aluminium ini adalah Ni (Nikel) sebesar $0,035 \%$ pada paduan pertama dan $\mathrm{Ni}$ (Nikel) sebesar 0,025\% mengalami kenaikan sebesar $0,001 \%$ pada dasarnya Nikel mempunyai keuntungan tahan temperatur tinggi dan menurunkan jumlah kerusakan Fe beserta kerugian melemahkan daya gigitan pada hasil peleburan.

Unsur paduan pada paduan aluminium ini adalah $\mathrm{Ca}$ (Kalsium) sebesar 0,0027\% pada paduan pertama dan $\mathrm{Ca}$ (Kalsium) sebesar 0,051\% mengalami kenaikan sebesar $0,0483 \%$ pada dasarnya Ca (Kalsium) Memperbaiki mampu mesin, menyebabkan cacat pada paduan pengerjaan panas, menimbulkan hot crack (retak) dan meningkatkan mampu mesin.

Dari kedua peleburan diketahui adanya kehilangan unsur karena proses peleburan (melting) kedua nilai kekerasannya meningkat lebih baik. Sedangkan seperti diketahui alumunium hasil pengecoran menggunakan unsur paduan utamanya menggunakan Seng ( $\mathrm{Zn}$ ) diketahui umumnya akan meningkatkan sifat-sifat mekanik pada perlakuan 
panas, juga kemampuan mesin. Akan tetapi efek merugikan seng lainnya adalah menurunkan kemampuan cor, meningkatkan kecenderungan terjadinya stress corrosion cracking, shrinkage, dan retak karena panas.

\section{KESIMPULAN}

1. Perancangan dapur crucible adalah sebagai berikut:
a. Dimensi dapur:
- Diameter dinding luar $\quad: 457 \mathrm{~mm}$
- Tebal dinding luar $\quad: 3 \mathrm{~mm}$
- Tinggi dapur $\quad: 410 \mathrm{~mm}$
b. Cawan lebur:

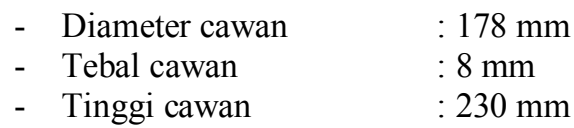

2. Dari analisa pengujian komposisi kimia menunjukan bahwa material pertama masih mengandung aluminium (Al) 89,52\% sedangkan paduan utamanya adalah seng (Zn) $7,71 \%$ dan Silikon (Si) $1,84 \%$ dan pada peleburan kedua masih mengandung aluminium (Al) 89,55\% sedangkan paduan utamanya adalah seng $(\mathrm{Zn})$ 7,51\% dan Silikon (Si) 1,94\% .

\section{DAFTAR PUSTAKA}

[1] Akuan, A., 2009. "Tungku Peleburan Logam", Universitas Jendral Ahmad Yani, Bandung.

[2] Sudjana, H., 2008, Teknik Pengecoran Logam, Departemen Pendidikan Nasional, Jakarta.

[3] Hill, R., C., 1979, "Design, Construction and Performance of Stick-Wood Fire Furnace for Residental and Commercial Application" University of Maine Orono, Maine, pp. 1- 7.

[4] Mubarak, A., Z., dan Akhyar, 2013, "Perancangan dan Pembuatan Dapur Peleburan Logam dengan Menggunakan Bahan Bakar Gas (LPG)" Jurnal Teknik Mesin Unsyiah, Vol. 1, No. 3 Juni 2013 pp. 128-132.

[5] Arianto, L.S. Dkk, 2014, "Tungku Pelebur Alumnium Dengan Economizer" Universitas Negeri Yogyakarta.

[6\} John R. Brown,. 1994, Feseco Non-Ferrous Foundryman's Handbook Eleventh edition Revised and edited.

[7] Totten, George. E, 1999, Handbook of Aluminium, Vol. 1, Marcel Dekker, New York, Bassel.

[8] Inayah Fatwa Kurnia Dewi, 2009, "Pemanfaatan Gas" Universitas Indonesia, Jakarta.

[9] Darmawan, H, 2004. Pengantar Perancangan Teknik (Perancangan Produk). Bandung.

[10] Suhandri E., 2011, "Rancang Bangun Dapur Peleburan Alumunium Bahan Bakar Gas", Politeknik Negeri Sriwijaya, Palembang. 